\title{
From Love Jihad to Grooming Gangs: Tracing Flows of the Hypersexual Muslim Male through Far-Right Female Influencers
}

\author{
Eviane Leidig
}

check for updates

Citation: Leidig, Eviane. 2021. From Love Jihad to Grooming Gangs: Tracing Flows of the Hypersexual Muslim Male through Far-Right Female Influencers. Religions 12: 1083. https://doi.org/10.3390/ rel12121083

Academic Editor: Aje Carlbom

Received: 19 September 2021

Accepted: 28 October 2021

Published: 9 December 2021

Publisher's Note: MDPI stays neutral with regard to jurisdictional claims in published maps and institutional affiliations.

Copyright: (C) 2021 by the author. Licensee MDPI, Basel, Switzerland. This article is an open access article distributed under the terms and conditions of the Creative Commons Attribution (CC BY) license (https:/ / creativecommons.org/licenses/by/ $4.0 /)$.
MF Norwegian School of Theology, Religion and Society, 0302 Oslo, Norway; eviane.leidig@mf.no

\begin{abstract}
This article traces the transnational flows of constructions of the hypersexualized Muslim male through a comparative analysis of love jihad in India and the specter of grooming gangs in the UK. While the former is conceived as an act of seduction and conversion, and the latter through violent rape imaginaries, foregrounding both of these narratives are sexual, gender, and family dynamics that are integral to the fear of demographic change. Building upon these narratives, this study analyzes how influential women in Hindu nationalist and European/North American far-right milieus circulate images, videos, and discourses on social media that depict Muslim men as predatory and violent, targeting Hindu and white girls, respectively. By positioning themselves as the daughters, wives, and mothers of the nation, these far-right female influencers invoke a sense of reproductive urgency, as well as advance claims of the perceived threat of, and safety from, hypersexualized Muslim men. This article illustrates how local ideological narratives of Muslim sexuality are embedded into global Islamophobic tropes of gendered nationalist imaginaries.
\end{abstract}

Keywords: love jihad; grooming gangs; Hindu nationalism; far/alt-right; influencers; social media; Islamophobia; gender; nationalism

\section{Introduction}

While tropes of love jihad are predominately centered within India and neighboring geographies in South and Southeast Asia, it is rarely conceptualized beyond this region. Love jihad refers to the phenomenon of Muslim men who intentionally seduce and convert Hindu women as an act of Islamization. The contributions to this Special Issue attempt to expand our theoretical boundaries of love jihad as an analytical concept, as well as an empirical category. This article builds upon this collective effort by positioning the specter of Muslim male hypersexuality as an integral element within two distinct nationalist myth-making movements: Hindu nationalism and the European/North American farright. It traces how gendered constructions of femininity and masculinity relate to, and are simultaneously informed by, projections of the Muslim "other" as barbaric, savage, and deviant.

Although such Islamophobic portrayals are not necessarily new, as discussed in this Special Issue, this article emphasizes the novelty of mediums through which the message is delivered-social media influencers. To date, few studies have explored the role of influencers in contemporary far-right movements (Lewis 2018, 2020), with a focus on women almost entirely absent (for an exception, see Maly 2020) and any focus on Hindu nationalist women is non-existent. Thus, this article examines how female influencers within the Hindu nationalist and European/North American far-right milieus circulate visuals and text on YouTube, Instagram, and Twitter to contribute to the narratives of an existential Muslim threat to Hindu and Western civilization. When analyzed comparatively, these narratives share a common trope of depicting Muslim men as hypersexualized, predatory, and violent figures that are seeking to target vulnerable "native" women as an act of Islamization of India and Europe. This article focuses in particular upon two case 
studies to represent these narratives: the incident of Nikita Tomar as an act of supposed love jihad in India, and the so-called grooming gang scandals in the UK. In addition to analyzing the social media content that is produced and circulated by these far-right female influencers, they amplify other key figures who serve as nodes that bridge the Indian and Western far-right milieus, further reinforcing the transnationality of the hypersexual Muslim male trope. What emerges are overlapping themes between the Hindu nationalist and European/North American far-right that pivot shared anxieties about the politics of reproduction as being linked to gendered nationalist imaginaries.

\section{Background}

This article bridges two bodies of literature-the role of women in Hindu nationalism and the far-right, and influencer culture in media studies - to inform its theoretical and, guided by the latter, methodological framework. Scholarship on women's involvement in Hindu nationalism, commonly known as Hindutva, which is a far-right ideology (see Leidig 2020a), focuses on a long history of participation in established Hindu nationalist organizations, most of which are composed of female-only wings of male groups. These female-only organizations, modeled after their male equivalents, include the Rashtra Sevika Samiti (sister wing of the Rashtriya Swayamsevak Sangh) established in 1936, Mahila Morcha (sister wing of Bhartiya Janata Party) established in 1980, Matri Shakti (sister wing of Bajrang Dal) established in 1984, and Durgha Vahini (sister wing of Vishwa Hindu Parishad) established in 1991. Often, female members of these organizations have familial relations with men in their counterpart organizations (Bacchetta 1993; Sarkar 1993; Menon 2010), and it is common for women to be affiliated to more than one organization. The organizations are extremely hierarchical and structured in order to demand absolute obedience and discipline from members. Although the demographic of women involved in these organizations is broad, the leadership is almost always comprised of middleclass, upper-caste women, who are frequently related to male leaders in the parallel men's organizations.

Similarly, much of the scholarship on European far-right women focuses upon their roles in political parties or social movement organizations (Köttig et al. 2017; Dietze and Roth 2020; Spierings et al. 2015; Pilkington 2017), with a few prominent female party leaders, such as Marine Le Pen of the National Rally in France (predecessor of her father, Jean Marine Le Pen), or Alternative for Germany's leader Alice Weidel. More recently, the visibility of these women is asserted by the European far-right through the lens of gender equality vis-à-vis Muslim immigrants who supposedly engage in oppressive gender practices in the name of Islam. This type of framing is described by Farris (2017) as "femonationalism," or the emancipatory rhetoric of women's rights in which the discourse mobilizes on "the profound danger that Muslim males constitute for western European societies, due, above all, to their oppressive treatment of women" (p. 2). Although this discourse is derived from some feminist agendas, Farris argues that it is simultaneously articulated by right-wing nationalist and neoliberal actors to advance their ideological claims. This exploitation of anti-Islam themes in order to proclaim gender equality has become weaponized by the European far-right to portray Muslim male sexuality as an existential threat to "native," white European women, who are in constant fear of sexual subjugation.

One of the most visible, contemporary proponents of this discourse is the Identitarian Movement (also known as Generation Identity), a youth-led, pan-European social movement that seeks to "restore" Western civilization through metapolitical action and activism. The Identitarian Movement is the modern-day legacy of the European Nouvelle Droite (New Right), specifically Groupement de Recherche et d'Études pour la Civilisation Européenne (Research and Study Group for European Civilization), which proposed an intellectual framework to challenge the supposed ideological hegemony of the dominant leftist elite as a reactionary backlash to 1960s counterculture (Bar-On 2007; Šima 2021). Today, the ideas that were developed by the Nouvelle Droite, e.g., loss of cultural identity as a result of immigration, have been crystallized through the Identitarian Movement and adapted 
toward contemporary debates. Employing confrontational tactics and social media campaigns, "a recurring theme of the Identitarian activists has been the protection of European women against the advances of Islam. Because 'European women' and 'especially the young ones' are the 'first victims [through verbal and physical attacks] of the Islamization of our society'," which is presented as sensationalized stories of rape through warnings of demographic warfare (Zúquete 2018, p. 185).

Scholarship on the North American far-right focuses upon organizations rather than parties, predominantly on white supremacist and Christian Identity movements, as well as Neo-Nazi groups. The role of women in these far-right social movements is to reproduce gender and racial hierarchies (Blee 2002; Darby 2020). Similar to their European counterparts, far-right women's sexuality is positioned as being under constant threat in which the "mobilization of white fears and anxieties about the virtue of white womanhood ... is imperiled because of the 'rape' of white women by non-white men" (Mattheis 2018, p. 149). Although in the US context, such non-white men are historically black male figures, this has slowly transitioned to include Muslim men with the ascent of the counter-jihad movement post-9/11. The policing of white women's bodies is justified by white men as protection from these hypersexualized, menacing threats; white men are motivated to defend "their" women and families as an extension of Western civilization. Accordingly, women's involvement centers upon traditional, heteronormative gender roles that are premised on the archetypes of femininity and masculinity. Their primary function is to serve as wives and mothers for the movement, what Mattheis terms "alt-maternalism", or "new maternalist logics paired with anti-multiculturalism, white ethno-nationalism, and hate frameworks" (p. 143). This alt-maternalism becomes racialized into the desire for family and stability.

Likewise, the fundamental role for Hindu nationalist women emphasizes their responsibility as mothers and wives (Menon 2010, p. 6). Through the politics of reproduction, Hindu nationalist women view their duty as caretakers, raising the next generation of militant Hindu nationalist men. Accordingly, constructions of femininity are symbolized through the idolization of Hindu goddesses, who, as different avatars, represent different facets of womanhood (Bacchetta 1993). For Hindu nationalist women, achieving this ideal feminine type creates purpose, fulfillment, and self-agency.

There are, however, distinct differences between the positioning of women in Hindu nationalism and the European/North American far-right. One particularly unique aspect is the acceptance of Hindu nationalist women's presence and activism in public space, which challenges the convention in conservative Indian society. However, by acting within the parameters of social acceptance, namely, through embodying an ideological and political conviction that reproduces patriarchal conditions, this allows Hindu nationalist women to openly express their activism without reprimand. As Menon (2010) describes:

The imaging of women as mothers of the nation enables Hindu nationalist women, many of whom come from very conservative social backgrounds, to be active outside the immediate confines of their biological families. While their participation in the public sphere might not have been tolerated otherwise, their activism in what has been carefully constructed as a moral/religious movement is deemed not only acceptable but necessary, given their roles as cultural reproducers of the nation. (p. 7)

The empowerment and sense of worthiness that is enjoyed by Hindu nationalist women in the public domain should thus be accounted for when compared to their role in the domestic sphere. Due to their welcomed presence in public, Hindu nationalist women have, on multiple occasions, also played a visible role in inciting and participating in violence at rallies, campaigns, and other events (Sarkar 1993, pp. 16-17) —a stark contrast to the submissive homemaker.

An additional significant difference between Hindu nationalist and Western far-right women is that the former encourages building physical strength through rigorous training exercises, such as martial arts and shooting drills. This attention to bodily defense, however, 
is solely possible due to the expectations placed on Hindu women to serve their primary function as wives and mothers. In their wife role, these women expect performances of masculinity and protection from their husbands; as mothers, they are required to promote fearlessness and reverence for the Hindu nation upon their children (Sethi 2002, p. 1548). Most importantly, Hindu nationalist women are permitted to engage in activities that build physical strength given that they face one singular threat: the hypersexualized Muslim male. The "specter of the Muslim male who has engaged in sexual violence against Hindu women in the past or the present, provides the primary justification for Hindu nationalist violence against the Muslim minority in India today" (Menon 2010, p. 12). The Muslim male "other," portrayed through his violent and aggressive behavior, is framed according to gendered nationalist imaginaries as alien and perverse. Hindu nationalism promotes a revisionist historiography of Muslim "foreign" invasion upon "indigenous" Hindu civilization, with that legacy reflected in contemporary religious communal relations. Muslims are, to this day, viewed as "anti-national," engaged in a secret plot to "Islamize" India, and using tactics such as "love jihad" in order to achieve their dominance. Thus, within Hindu nationalist ideology, Hindu women represent the daughters of Bharat Mata (Mother India), and an attack on a Hindu woman is considered by extension to be an attack on the nation herself.

Both Hindu nationalist and Western far-right imaginaries share the myth of the hypersexualized Muslim male as a relic of colonial epistemologies. Indeed, such constructions of the predatory Muslim man originate from the British colonial period in India (Menon 2010, pp. 37-38), resulting from categories of divide-and-rule between Hindus and Muslims. Similarly, European-supported Orientalist schools of thought cultivated the figure of the Muslim male according to essentialist depictions as sexually aggressive, violent, and uncivilized. These "othering" processes would serve as a precursor for modern Islamophobia and related far-right conspiracies, such as the Eurabia theory (Bangstad 2019) and more recently, the Great Replacement. The Great Replacement theory was initially developed by French philosopher Renaud Camus, in which indigenous French people would be demographically replaced by non-European people, specifically immigrants from Africa or the Middle East, in a deliberate plot fostered by elites. Camus' notion of the Great Replacement has intellectually influenced the European Nouvelle Droite (New Right) and the Identitarian Movement.

In particular, this article focuses upon the counter-jihad movement that peaked during the late 2000s/early 2010s and would merge into the so-called "alt-right" and Identitarian Movement of the late 2010s/early 2020s. The key figures, discussed below, play a key role in facilitating a transnational connection between the Islamophobic tropes of "love jihad" and Western far-right representations of Muslim men through so-called "grooming gangs." Utilizing a comparative analysis, this article highlights that the construction of "native" (i.e., Hindu and white in India and Europe/North America, respectively) femininity is threatened by, and in need of protection from, violent, hypersexual Muslim masculinity. These gendered nationalist representations are weaponized by Hindu nationalist and Western far-right women to claim dominance over the Muslim body as a tool of reproductive politics.

Before turning to the methodology and data sections, this article also draws upon another body of literature to situate the case studies. Driven by a media studies approach, this article employs the term "influencers" to describe the women that were identified and analyzed for the findings. Influencers are here defined according to Abidin (2015) as "everyday, ordinary Internet users who accumulate a relatively large following on blogs and social media through the textual and visual narration of their personal lives and lifestyles, engage with their following in 'digital' and 'physical' spaces, and monetize their following by integrating 'advertorials' into their blog or social media posts and making appearances at events". Although influencers encompass a broad array of topics and genres, the focus of this article is on the women involved in the Hindu nationalist and European/North American far-right movements discussed above. 
Building upon Lewis (2018), who conceptualizes an "alternative influence network" of far-right YouTubers in North America and Europe, these influencers "build audiences and 'sell' them on far-right ideology" by cultivating intimate and accessible relationships with viewers of their content (p. 4). These far-right influencers effectively merge political content with personal branding techniques in order to gain an audience and, over time, fans. Maly (2020) describes a similar effect as "networks of influence," in which "the more people follow an influencer, the more chances that their content will be liked, shared, and distributed in the network" (p. 4).

Influencers similarly use Instagram to attract and maintain followers. Marwick labels this "Instafame" as "a variety of microcelebrity," or "a mind-set and a collection of selfpresentation practices in social media, in which users strategically formulate a profile, reach out to followers, and reveal personal information to increase attention and thus improve their online status (Senft 2013)" (Marwick 2015, p. 138). Through a strategic presentation of relatability and accessibility, influencers are able to cultivate a fan base of admirers. Further discussed in the findings below, Hindu nationalist and European/North American far-right female influencers engage in such practices of the "attention economy" to generate clicks, likes, and comments. They operationalize the affordances of social media platforms in order to promote their personal brands in accordance with a political ideology.

This recognition and exploitation of the underlying platform affordances by influencers is especially important. "Influencer culture is thus a socio-technical assemblage: the voice and performance of the social media influencer is not entirely 'free,' but a product of socio-technologic interaction between the vlogger, the platform(s), his or her followers, and the larger niche in which the influencer acts" (Maly 2020, p. 4). In short, being an influencer is not just attracting followers through personality type, but understanding that popularity is obtained with deep knowledge of the platform itself. Influencers use different platforms for different purposes; they know what their audience wants but also how to deliver their message most effectively.

While the scholarship on far-right influencers focuses almost exclusively on actors based in North America and Europe, far-right digital culture in India has been observed through the rise in social media popularity and mobilization surrounding Prime Minister Narendra Modi. In representing the vision of India becoming a techo-economic powerhouse of the twenty-first century, i.e., the New India, Modi's ascent to power built upon his charismatic, accessible, and relatable image (Ahmed et al. 2016; Chadha and Guha 2016; Pal 2015; Chakravartty and Roy 2015). The young, technologically savvy-oriented Hindu nationalist digital apparatus supporting Modi can be characterized as a vast network of "Internet Hindus." Frequently recruited by Modi's BJP party to push anti-Muslim and anti-left content online, the Internet Hindu, who is almost always male, proud, and aggressive (Mohan 2015; Udupa 2018), helps construct the narrative of Modi as a figure that is capable of restoring the lost glory of the Hindu rashtra (state). This massive digital army, largely composed of volunteers, feels intimately connected to Modi and the broader Hindu nationalist movement by virtue of what Govil and Baishya (2018) describe as a "technoculture," or the "sociopolitical experience through technological fantasies of virtual access, affective mobilization, and political action" (p. 69). Driven by a united ideology and sense of belonging, these Internet Hindus partake in online activities through the promise of a one-on-one interaction with Modi who will, on occasion, interact with a common person. This type of personalization echoes much of the relationship between an influencer and a fan, as discussed above. However, this article makes a departure by examining the understudied phenomenon of Hindu nationalist influencers- those deeply connected to the leadership who are able to cultivate a following of Internet Hindus. In particular, these influencers draw upon and benefit from the Hindu nationalist technoculture, but such a relationship has not been explored in depth. Thus, this article contributes toward a nuanced understanding of the processes that unfold between influencers and followers within the broader digital Hindu nationalist apparatus. 
In the following sections, this article comparatively explores how Hindu nationalist and European/North American far-right female influencers portray two events: the murder of Nikita Tomar as an incident of love jihad in India, and the Telford grooming gang scandal in the UK. Both case studies illustrate how local ideological narratives of Muslim male hypersexuality are embedded into global Islamophobic tropes of gendered nationalist imaginaries. Following an analysis of these case studies is a brief examination of key figures that act as a transnational bridge between Hindu nationalist and European/North American far-right milieus. First, however, a brief description of the methodological approach and materials is discussed.

\section{Methodology}

In order to explore the case studies below, this article utilizes a discourse and visual analysis of selected YouTube, Instagram, and Twitter influencers' accounts. For the Hindu nationalist female influencers, this includes Priti Gandhi (national social media convenor for Mahila Morcha, the woman's wing of the BJP), Shefali Vaidya (journalist for far-right media outlets Swarajya Magazine and OpIndia), Apurva Singh (head of IT for the BJP's Delhi chapter), Arti Agarwal (intellectual and author), and Ritu Rathaur (commentator/pundit). For the European/North American far-right female influencers, this article primarily focuses upon Brittany Sellner and Lauren Southern's profiles (both YouTubers and activists), and their links to Tommy Robinson, a key figure in bridging transnational narratives of love jihad and grooming gangs (discussed below).

All of these women are very active on social media for promoting their political ideology, but also in establishing a recognizable personal brand with fans. Although they address numerous topics on their accounts, this article focuses specifically on their responses to the Nikita Tomar incident and grooming gang activity for comparative analysis of Muslim male hypersexuality. It explores in depth their discursive strategies combined with their influencer presentation as a means of streamlining exclusionary nationalist movements for wide appeal.

\section{Data and Findings}

\subsection{The Case of Nikita Tomar}

In October 2020, a 21 year old woman named Nikita Tomar was shot dead by two men outside her university in Haryana, India. The incident was recorded on CCTV and investigations revealed that Tomar was murdered by two Muslim men. What followed shortly after this tragedy was a massive uproar. Hindu nationalist activists quickly labeled the incident as one of love jihad, despite lack of confirmed information about the case (see Figure 1). It was only revealed months later that one of the perpetrators had been accused by Tomar's family in court of having stalked and pressured Tomar into marriage and conversion to Islam.

Images of Nikita Tomar flooded social media, including Instagram, where Hindu nationalist women spread narratives of love jihad. In Figure 1, the image on the left is an Instagram Story posted from the account of Priti Gandhi, who serves as the social media national convenor of the female-only Hindu nationalist organization Mahila Morcha. The post reads, "Shot dead by Tauseef in broad daylight for refusing to convert and marry him," assuming that Tomar was a victim of love jihad. Gandhi posted about the incident on Twitter as well (see Figure 2), warning that those who deny the existence of love jihad (i.e., Hindus) may face a similar fate.

Similarly, the image in the middle of Figure 1 is an Instagram post by Shefali Vaidya, a right-wing journalist who opines columns for media outlets such as Swarajya Magazine and OpIndia. Here, Vaidya writes in the description of the post that Tomar was targeted "because she refused to convert to Izlam [sic] and marry him," once again implying a case of love jihad. Given both Vaidya and Gandhi's roles as mothers, the outrage that they express toward Tomar's death is framed as a maternalist concern, as the protection of "our" 
daughters from malicious intent. This affords them a voice and platform in the Hindu nationalist milieu.
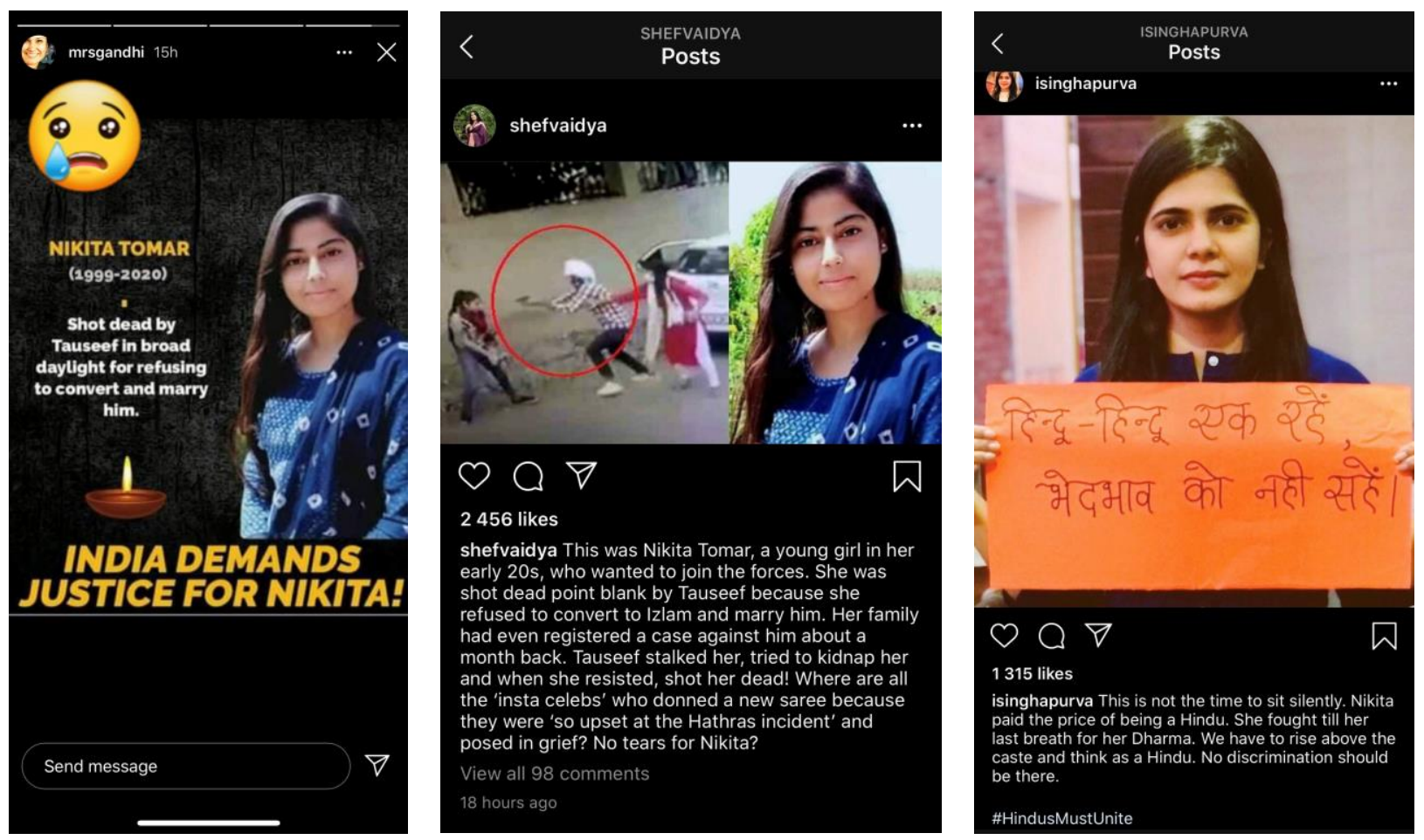

Figure 1. Instagram images taken from three female Hindu nationalist influencers responding to Nikita Tomar's death.

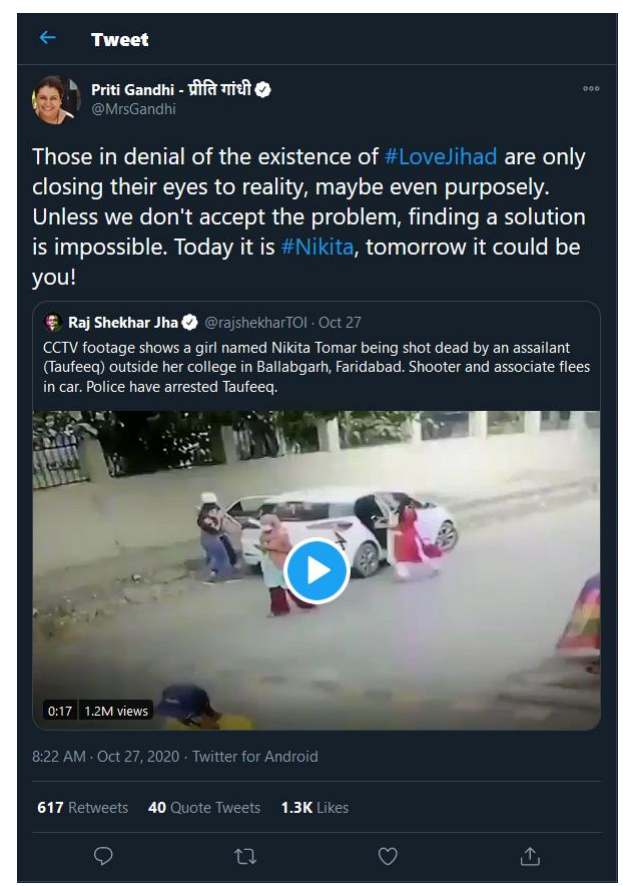

Figure 2. Tweet by Priti Gandhi about the circumstances of Nikita Tomar's death as an act of love jihad.

Meanwhile, other female Hindu nationalist influencers participated in social media campaigns in order to spread awareness about Tomar's death, using activist toolkits, such as hashtags, which is a common tactic that is used by social movements (see Youmans and York 2012). The image on the right in Figure 1 features an Instagram post by Apurva Singh, head of the BJP's IT cell in Delhi (which corresponds to a head of digital communications 
role). Here, Singh is holding up a poster in Hindi that translates to "Hindus are one, don't stand for discrimination." She is reinforcing the trope that Islam is violent and intolerant, as opposed to Hinduism, which is peaceful and tolerant in contrast. In the description below, Singh writes that "This is not the time to sit silently. Nikita paid the price of being a Hindu. She fought till her last breath for her Dharma. We have to rise above the caste and think as a Hindu. No discrimination should be there. \#HindusMustUnite."

A call for unity amongst Hindus, irrespective of caste, is underscored by an element of urgency: Tomar "paid the price of being a Hindu" implies that all Hindus face an existential threat from Muslims who are intent on seeking retribution. The reference to dharma in the description signals that Tomar was resisting forced conversion to Islam by adhering to her moral and spiritual duties within Hinduism. Further, there is an interesting interplay with the word choice of "discrimination" used by Singh. Here, she calls upon all Hindus to unite and not discriminate, and yet, she is stereotyping a community of individuals who belong to a singular religion (i.e., Muslims) as being collectively discriminatory. The use of "discrimination" also links to Hindu nationalists' critique of so-called "pseudo-secularism" from the political left, and the construction of the Hindu majority as being discriminated against by pandering to religious minorities, commonly known as minority "appeasement" (see Saxena 2018; Bhatt 2004, p. 134). According to this logic, Hindus face discrimination as a majority that have become a minority in their own homeland.

Most importantly, these female Hindu nationalist influencers are exploiting the tragedy of a young Hindu woman's death in order to promote a nationalist agenda. By politicizing her age and religion, and circulating her photo, this becomes weaponized as a means to assert fear of young Muslim male sexuality. Labeling the incident as a case of love jihad, without full knowledge of the situation, reproduces Islamophobic tropes of predatory Muslim men. Incidents in which young Hindu women face abusive and aggressive behaviour from Hindu men is unacknowledged as it fails to serve the Hindu nationalist myth-making of Hindu women in need of protection from Hindu men.

Reactions to Nikita Tomar's death by Hindu nationalist women on social media builds upon their previous efforts to promote conspiracy theories of love jihad online. Arti Agarwal is an influencer who runs a YouTube channel called Ishittva, which aims to "revive Hindu culture," along with a complementary website to raise awareness of Hindu persecution. ${ }^{1}$ Agarwal uploads regular videos in which she discusses intellectual topics related to Hinduism, but also more conspiratorial content of instances of Hinduphobia and systematic genocide of Hindus. One of her most popular videos, titled "Hindu Genocide: Wake Up Hindus," features a segment on love jihad (see Figure 3).

Agarwal claims that more than one hundred girls per day are victims of love jihad (without providing a source for the statistic) as part of an ongoing genocide of Hindus. The contemporary perpetrators of this genocide are Muslims-historical perpetrators include British colonizers in addition to Muslims-seeking to dominate Hindu populations.

Blending together Islamophobic far-right narratives along with conspiracy theories on social media is not a new phenomenon for far-right YouTubers (see Lewis 2020). However, Agarwal's performance as an intellectual makes a distinct departure in providing an aura of legitimacy for her claims. The types of microcelebrity practices that she engages in on YouTube are not necessarily framed by revealing personal information, but she creates authenticity and relatability instead through acting as a religious guru in an intimate setting, which is then weaved into a nationalist myth of Hindu identity. ${ }^{2}$ This affords her a public profile that is accepted within a conservative society given that her activism constitutes a moral and religious conviction. Reinforcing tropes of love jihad is thus part of a wider mission to promote the Hindu nation as a civilization in jeopardy.

Within the discourse on love jihad, there are commonly attributed "enemies" that are considered to be responsible, as highlighted in a tweet by female Hindu nationalist influencer and political pundit Ritu Rathaur in Figure 4. Here, Rathaur alleges that the film entertainment industry (i.e., Bollywood), the mainstream media, and left-wing individuals are responsible for allowing love jihad to occur. 


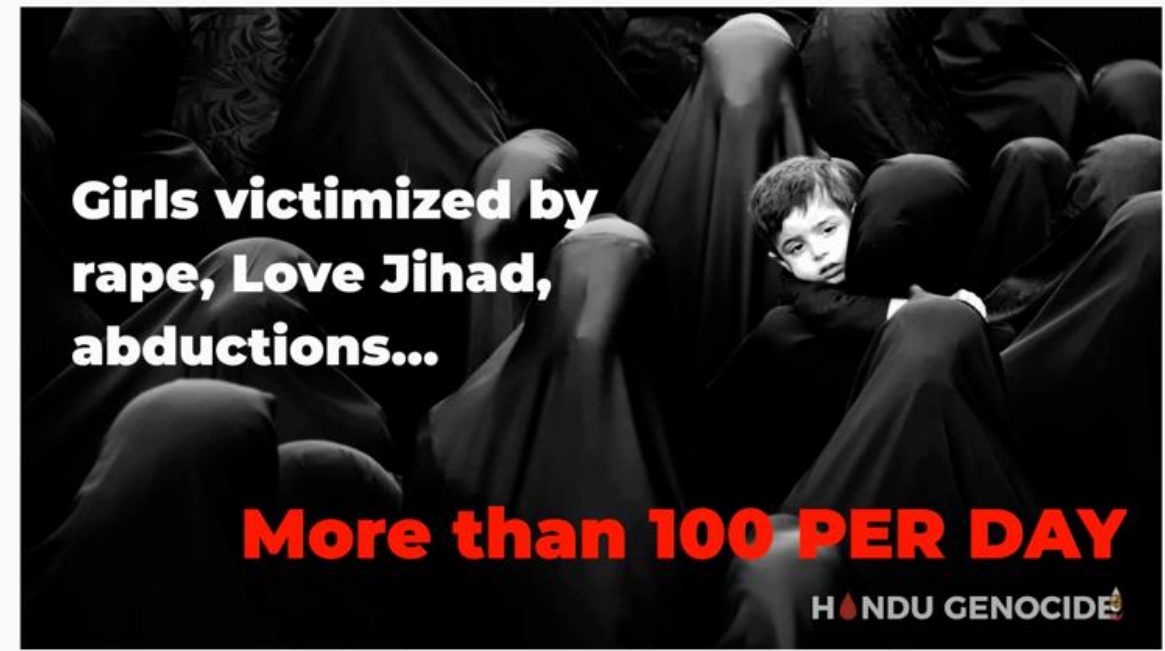

Hindu Genocide: Wake Up Hindus

3,848 views $\cdot$ Sep 1,2019

16 267 I $22 \rightarrow$ SHARE $\equiv+$ SAVE $\ldots$

(2) Ishittva

SUBSCRIBE

The untold genocide of Hindus: The biggest, longest, ONGOING genocide in the history of mankind.

Contribute to our mission: instamojo.com/@ishittva

SHOW MORE

Figure 3. A screenshot from a YouTube video by Arti Agarwal on love jihad.

Ritu (सत्यसाधक) \#EqualRightsForHindus

@RituRathaur

Replying to @RituRathaur

Love jihad packages as love by bollywood, media, liberals ..

Hindu girls are the bed rock of hindu civilization , the carriers of future generations \& they want one womb less ...All the time.. Hindu society must give a befitting reply!

6:39 AM - Feb 1, 2021 - Twitter for Android

95 Retweets 3 Quote Tweets 171 Likes

Q

$\uparrow\urcorner$

O

Figure 4. Tweet by Ritu Rathaur on the perpetrators of love jihad.

Rathaur lists these "enemies" as supposedly liable for allowing Muslim men to seduce and convert young Hindu girls into Islam. This is a striking parallel to the narrative of Western far-right influencer discourse concerning the "out-group" of "mainstream media, Hollywood and the [ideologically left oriented] 'political class'" (Maly 2020, p. 6), which is a similarity that is discussed further below. Notably, Rathaur also incites a call for action in which "Hindu society must give a befitting reply!" thus suggesting violence as retribution 
and building upon the legacy of Hindu nationalist women who have played a visible role in encouraging violence within public spaces.

By attributing these "enemies" as being anti-“Hindu civilization," this brings forth what Brubaker argues as a shift from nationalism to "civilizationism" by far-right actors, "driven by a striking convergence in the last fifteen years around the notion of a civilizational threat from Islam" (Brubaker 2017, p. 1193). As Brubaker explains, "civilizationism can be understood as a form of nationalism, as a way of talking about 'the nation'" (p. 1211). According to the ideology of Hindu nationalism, being a Hindu is not only a national identity, but a civilizationalist identity that is built on an irredentist myth of Akhand Bharat (Undivided India), in which the modern day nation-state of India includes the borders of Pakistan, Bangladesh, Nepal, Afghanistan, parts of Myanmar, and Sri Lanka under one geography.

This type of civilizationist rhetoric gained traction with the rise of the European/North American counter-jihad movement from the late 2000s to mid-2010s (Pertwee 2020), which promoted Huntington's "clash of civilizations" concept to frame Western civilization as being under attack from Islamic civilization. At the forefront of this effort in the UK was British far-right activist Tommy Robinson (real name Stephen Yaxley-Lennon), founder of the protest group English Defense League in 2009. This article will discuss Robinson's key role as a bridge between disparate Islamophobic movements, but first turns to the narrative of grooming gangs as perpetrated by female North American far-right influencers.

\subsection{Grooming Gang Scandals}

In the UK, the phenomenon of child sexual exploitation gangs, commonly referred to as "grooming gangs," has become a well-known topic in national media and political discourse-noted also by Sian in this Special Issue. As described by Cockbain and Tufail (2020), the "central argument of the 'grooming gangs' narrative is, in short, that a 'disproportionate' number of Asian/Muslim/Pakistani-heritage men are involved in grooming (mostly) white British girls for organised sexual abuse. These claims are often substantiated with reference to a spate of high-profile prosecutions of so-called 'grooming gangs' in towns and cities such as Rotherham, Rochdale, Derby, Telford, Oxford, Huddersfield and Newcastle" (p. 4). Grooming gangs are not limited to sensationalism by the far-right in advancing anti-Muslim stereotypes, but can be constituted as part of a broader racialized discourse on crime that is articulated by a wide set of mainstream actors (Cockbain and Tufail 2020; Mondon and Winter 2017). This article, however, focuses specifically upon the role of far-right female influencers in perpetuating myths of grooming gangs as being integral to an Islamophobic agenda that is oriented toward Muslim male violent hypersexuality as a threat to gendered nationalist imaginaries.

American far-right YouTuber Brittany Sellner (née Pettibone)—who is married to the leader of the Austrian branch of the Identitarian Movement, Martin Sellner (discussed above) - has been highly vocal about grooming gangs. Posting an Instagram Story from the British tabloid Daily Mirror, the headline states: "'Nearly 19,000 children' sexually groomed in England in the past year" (Figure 5).

Sellner has previously created social media content on the topic of grooming gangs, often in collaboration with other far-right figures. In one YouTube video (Figure 6) with the Canadian far-right influencer Lauren Southern, the two discuss a recent, controversial case of grooming gang activity in Telford, a town located in the West Midlands of the UK.

Their dialogue for the video focuses upon grooming gangs as an epidemic, not just in the UK, but as part of a wider strategy of demographic warfare being plotted by Muslims. Sellner says in frustration:

Not even just the UK, all across Europe you've seen these terrible, just violent, brutal rapes and murders of girls. So, how is this still happening? And why is there not far more outrage about it? 


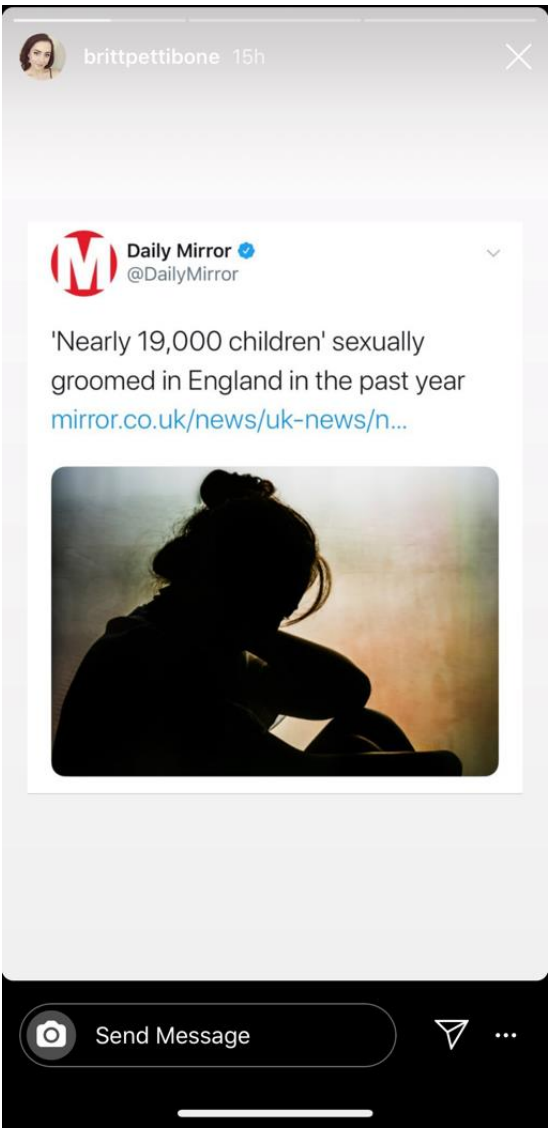

Figure 5. Instagram Story by Brittany Sellner on grooming gangs, accessed 30 December 2019.

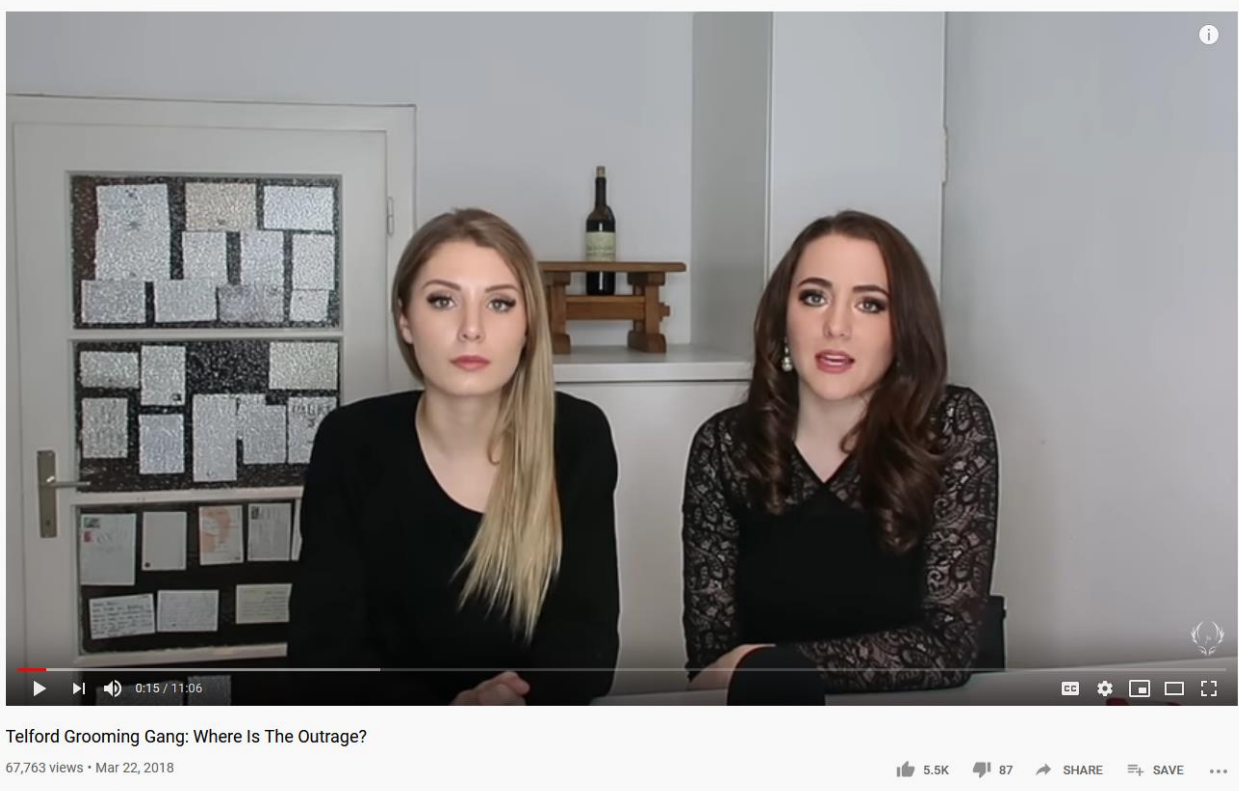

Q.) Brittany Sellner

Figure 6. YouTube video screenshot of Lauren Southern (left) and Brittany Sellner (right) discussing grooming gangs.

By specifying the "violent, brutal rapes and murders of girls," Sellner reinforces the trope of Muslim male sexuality as predatory and savage. She frames this behaviour along similar lines to the Eurabia theory, a conspiracy that Muslims are seeking the "Islamic 
penetration of Europe" (Bangstad 2013, p. 371), achieved in part by a demographic takeover. Southern responds by merging this narrative with an anti-immigration stance:

Not just across Europe, but this is clearly a culture that we're importing. You see this all across the Middle East and North Africa with these horrible human trafficking rings and rapes... When we import some of these cultures and these criminals to the West, we don't deal with them the way that we would deal with them if they were members of the United Kingdom or Canada initially, or actual legal citizens.

Here, Southern is equating Muslims and Islamic "culture" with "importation", thereby not only promoting negative stereotypes of Islam as oppressive, but also attributing grooming gang activity as a foreign practice that is connected to sexual slavery. The narrative being promoted is similar to Hindu nationalists positioning Muslims as "foreign" and displaying "anti-national" beliefs and practices. Southern also fails to acknowledge that the grooming gang perpetrators could be British citizens and assumes that immigration status plays a role in their abusive behaviour. This trope is repeated later in their conversation, in which she characterizes Muslims as an essentialist monolith:

This in-group preference culture ... There's communities that are so completely different than Western society, that it's just the culture there.

Sellner responds with fear mongering:

And having them co-exist, it's only going to end with one side consuming the other, becoming completely dominant. Without assimilation, like having them in and not even requiring that. It's going to end in disaster, absolute chaos.

Positioning Islamic "culture" as antithetical to the West echoes Huntington's (1993) clash of civilizations thesis, in which Western and Islamic civilizations will inevitably face conflict; this further builds upon Brubaker's concept of civilizationalism above. These two far-right female influencers use coded language such as "in-group", "communities", and "culture" to frame Muslims as fundamentally "Other": intolerant and unwilling to assimilate. What constitutes "assimilation" is unclear, although the underlying assumption is that Muslims are distinctly foreign and do not subscribe to Western values. This difference is allegedly manifested as sexual exploitation in grooming gangs.

Both Sellner and Southern blame "progressivism" and the police as fearful of being labeled "racist," as the reasons for allowing these grooming activities to continue. As Southern remarks:

[Telford is a government] cover up, particularly a cover up that right-wingers tend to expose. They tend to say, hey look, this multicultural mass migration maybe isn't all just rose coloured glasses.

Southern similarly attributes the media as responsible for turning a blind eye:

The mainstream media have been just as complicit in not talking about it.

Labelling left-wing politics as the "enemy" that influences state and public institutions, such as law enforcement and the media, is a common tactic amongst the far-right. By framing it as a "cover up," Southern positions herself and Sellner as exposers of "the real story," revealing to their audience valuable and secretive information. This strategy aligns with what Lewis (2020) describes as micro-celebrity practices of far-right YouTubers who use intimacy techniques to build credibility with their viewers while simultaneously discrediting mainstream media as biased toward "social justice politics" and silencing dissenting voices. Accordingly, Southern and Sellner posture themselves as arbiters of truth who warn of the dire effects of multiculturalism in Western societies, i.e., organized sexual exploitation of young women.

Grooming gang activity is thus formulated as part of a greater plan by left-wing politics to create a dystopian future. Southern states:

These people have spent so long saying this was a real refugee crisis. They spent so long saying this multicultural society will work fine, we just have tolerance, 
we're not going to have issues with authoritarian cultures, we're not going to have issues with cultures that are completely antithetical to Western society.

Here, "these people" and "they" refers to the left-wing oriented media and political establishment who favoured the intake of refugees into Europe during the crisis of 2015 (again, Southern is falsely conflating the grooming gang perpetrators with refugees). In describing Muslim immigrants as having "authoritarian cultures" that are tolerated by "native" Europeans, she warns that this will eventually accelerate into societal collapse with Islamic barbaric practices of female oppression. This rhetoric of "tolerance" bears striking resemblance to the discourse on "pseudo-secularism" and "minority appeasement" of Hindu nationalists, as highlighted above in Singh's post on Hindus facing discrimination. Here, we see a dual construction of the majority group, i.e., Hindus and white Europeans, as tropes of victimhood to mobilize outrage (see Ganesh 2020).

Indeed, Sellner reproduces this sense of urgency to act when discussing the horrific crimes that were committed by the Telford grooming gang. She details young victims suffering abuse through being drugged, beaten, and raped. This is all framed in her build up to demand retribution for the ringleader of the gang (who has a Muslim male name), as receiving a shorter prison sentence:

I don't understand why there isn't more outrage about this, why there isn't protests in the streets. A society that doesn't take care of its children, is not a society that's even worth fighting for.

By focusing upon the violation of children and their innocence, Sellner attributes this with the degradation of society. In particular, children symbolise the nuclear family unit as the foundation for a nationalist myth for the far-right. The vulnerability of children places women's roles as nurturers and men's role as protectors in far-right reproductive logics, echoing Mattheis' concept of "alt-maternalism" within alt/far-right communities. Another notable claim in Sellner's statement is the phrase "worth fighting for." As noted above, the far-right attributes European men for building Western civilization out of motivation for their women and children; the virtue of white womanhood is threatened by miscegenation and sexual impulses of non-white male migrants (Mattheis 2018, pp. 147-49). This narrative circulates amongst far-right social media accounts, such as the Instagram account worth_fighting_for, shown in Figure 7.

With the text displaying 'Remember what you are fighting for' overlaid across photos of four white women holding, presumably their, children, the implication is that Western civilization is facing an existential threat from outside forces intent on destroying white families. Similarly, by associating fighting against grooming gang activity with "fighting for" the survival of Western civilization, Sellner makes a dog whistle that portrays Muslim male hypersexuality as part of a greater scheme towards demographic warfare. Young white women must be protected as the reproductive vessels of the nation. In order to spread this call to action, Sellner and Southern ask their viewers and followers to share this information with their networks. Through mobilization, it may be possible to "save the West" from an Islamic invasion. One prominent figure within the far-right scene who has been campaigning on the issue of grooming gangs is British counter-jihad activist Tommy Robinson. Sellner and Southern identify him in their video as an exposer of the truth. The next section turns to another YouTube video on Sellner's channel that features a conversation with Robinson, titled "Fighting Islamization with Tommy Robinson." (Figure 8) ${ }^{3}$ 


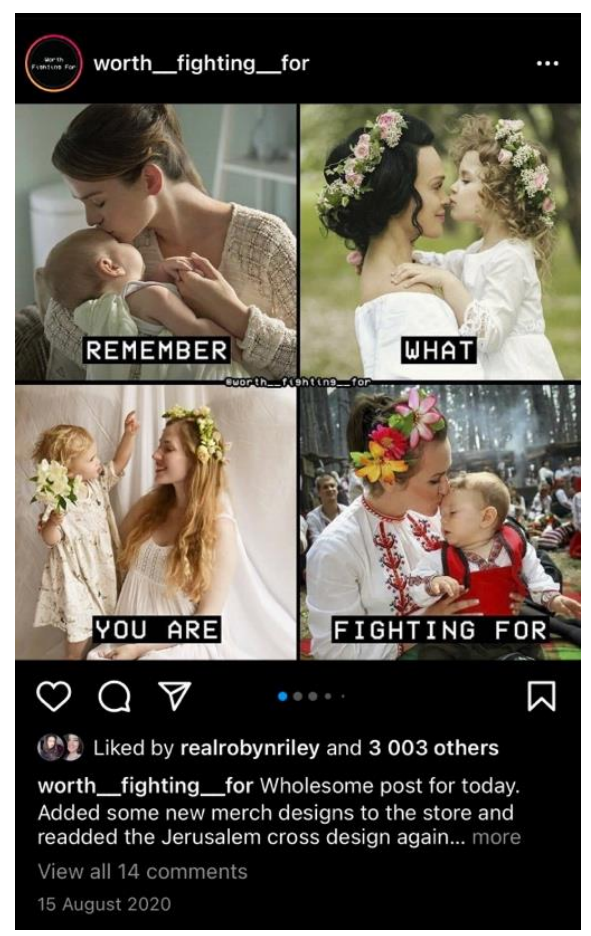

Figure 7. Post by Instagram account worth_fighting_for featuring four women and children.

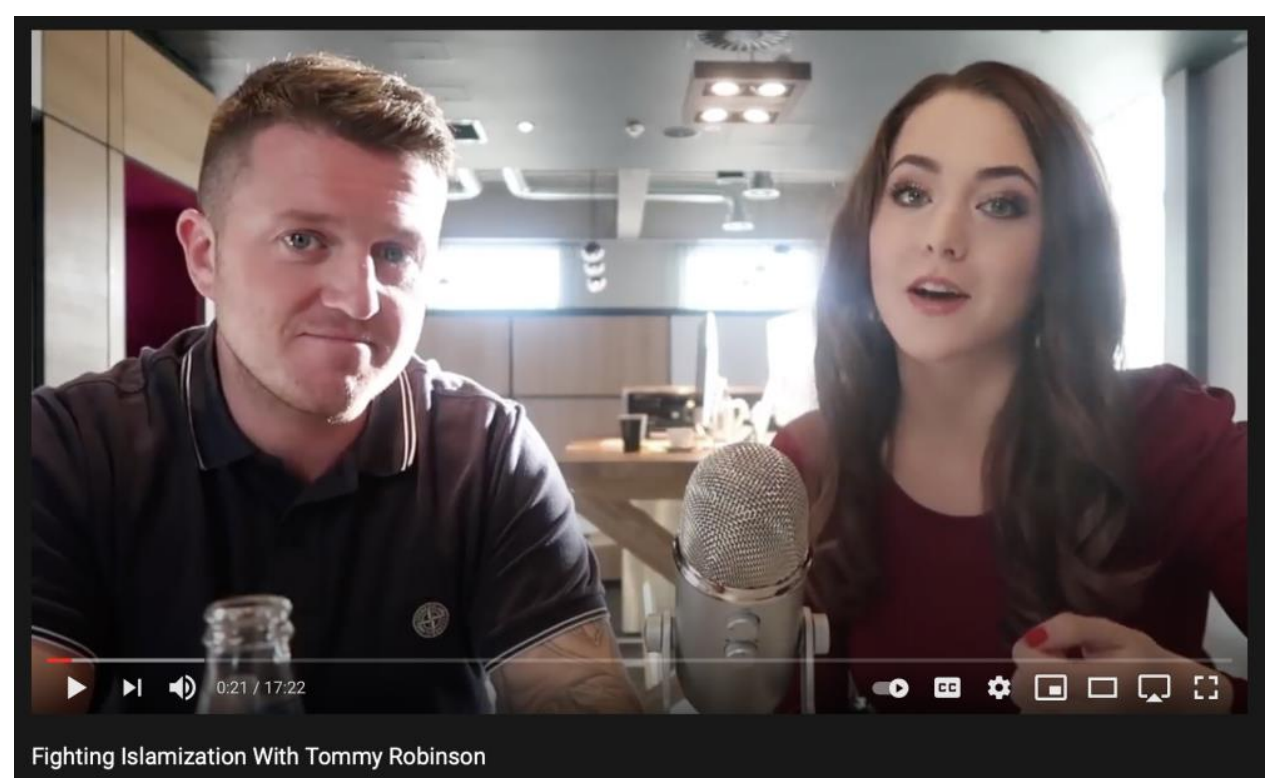

Figure 8. YouTube video screenshot of Tommy Robinson and Brittany Sellner in "Fighting Islamization with Tommy Robinson".

\subsection{Protecting "Our Daughters"}

Before Brittany Sellner and Lauren Southern's video discussing grooming gangs was released, Sellner had previously interviewed Tommy Robinson, an activist who she has featured on her channel on more than one occasion. ${ }^{4}$ In one particular interview, titled "Fighting Islamization with Tommy Robinson", (Figure 8) their conversation focuses upon Islam's incompatibility with the West. At one point, Sellner promotes the Great Replacement conspiracy theory:

Aside from the mass Islamization and the risk of terror attacks, are you also concerned about the fact that with so many people migrating, it will eventually 
replace the population ... Muslims will be the majority in Europe. This will replace the culture.

Sellner does not explicitly name the Great Replacement but rather alludes to the phenomenon of Muslims replacing the "native" European population through immigration and demographic warfare-a dog whistle for the Great Replacement. Muslims in particular are identified as a threat to white European populations according to the Identitarian Movement's interpretation of the Great Replacement theory (Davey and Ebner 2019, p. 7).

Although Sellner does not reference the Great Replacement by name, it is interpreted by Robinson as such:

When you talk about the Great Replacement ... the problems we already face, they're just going to explode ... That should be the biggest fear. The biggest weapon they use is we're only $5 \%$, we're only $6 \%$, we're only small numbers. But they know how quickly it can change. When you have in England-5.6 children, Muslims-in France 7.1, I believe, on average-multiple wives. That can like *snaps fingers*.

Here, Robinson is attributing Muslim ("they") reproduction rates as a "weapon" that is being deliberately employed against the European ("we") population. Citing sensationalist numbers of Muslim family sizes and inaccurate portrayals of polygamous relationships, Robinson engages in fear mongering that "native" Europeans will be eventually "replaced" by an oppressive Islamic regime that treats women as solely reproductive objects. His emphasis on the stealthy nature of this approach echoes the type of "creeping Islamization" or "creeping Sharia" rhetoric popular among the counter-jihad milieu (see Pertwee 2020). At the heart of this Great Replacement conspiracy is the role of Muslim male hypersexuality, which is depicted as barbaric, savage, and tyrannical.

Sellner and Robinson continue to negatively represent Muslims and Islam in warning about social repression. Similar to the above conversation on grooming gangs between Sellner and Southern, Robinson alerts to the dangers that are faced by non-Muslims living in heavily populated Muslim areas.

Do you think they'll show us the same rights when they become the majority? Just look in the areas where they have become the majority. Look in Luton, look in Bradford, look in Birmingham. Look at what it's like for non-Muslims living in those communities. Look at the persecution they face, look at the harassment they face, look at the rapes and the violence they face. We are sleepwalking into an oblivion.

By framing non-Muslims as facing persecution, harassment, and an epidemic of rape and violence (i.e., grooming gangs) instigated by Muslims, Robinson paints an urban dystopia, a "violent imaginary" of the far-right, which Thorleifsson (2019) describes as sites "where Muslim immigration has turned neighbourhoods into ghettos, sharia was practised and rape was commonplace" (p. 515). Sellner builds upon this alarmism in her response:

Absolutely. You also have to consider the things we'll be subjected to under their rule, like child marriage, for example, which you've mentioned is going on in the UK despite being illegal, but it's still going on.

Under "their" (Islamic) rule, practices such as child marriage are viewed as common place, an example of the pedophilia that is supposedly carried out by Muslim men upon vulnerable young victims. This perverse act, manifested in the grooming gang activity above, is seen to be a natural extension of religious practice, as dictated by Islam. Robinson reinforces this point:

And that's child marriage between Muslims. When you look at the prostitution of our daughters, which is again scriptured in the Quran, they can take non-Muslim women as sexual slaves.

To which Sellner simply replies:

They hate us. 


\section{Robinson agrees:}

They hate us. Or they view our women completely differently. They view our women as fair game.

Sellner concludes:

The cultures are completely incompatible. And a lot of people won't admit this.

In depicting Muslim men who seek "our daughters" or "our women" as "sexual slaves" (see Tebaldi in this Special Issue), Robinson reproduces a gendered nationalist imaginary that represents "pure" Western women as being threatened by the hypersexual impulses of Muslim men. When projected as an act of demographic warfare, the fertility of Western women becomes weaponized in policing bodies.

There is, however, an interesting shift in their conversation when Sellner brings up the issue of tolerance within multicultural societies:

And then there's the question of tolerance. Do you believe the Muslims, when they do become the majority, will be as tolerant of the natives as the natives are of them now? And this is I think a very important question to ask, that we need to ask.

In positioning Muslims ("they") versus "natives" ("us"), Sellner constructs a binary of assumed fundamental difference. Robinson replies with a surprising comparison:

Through tolerance we will ourselves become refugees. Just ask people in India, the same situation. Many of them have had to leave due to tolerance to Islam (emphasis added).

By stressing the Indian context, Robinson makes a direct connection between European/North American far-right and Hindu nationalist narratives concerning the role of Islam, and relatedly, how acts of tolerance lead to sexual domination and oppression by Muslims. This is linked to power dynamics over population control, which Robinson refers to as "refugee" status as a consequence of tolerating Islam.

Robinson is a figure who acts as a key node in bridging narratives of love jihad and grooming gangs as shared aspects of transnationality. His past activism includes bringing attention to the plight of Hindus and Sikhs who have "suffered 'genocide' under 'Islamic rule in India'"' (Leidig 2020b, p. 144). In his capacity as a reporter for Canadian far-right media outlet Rebel News, Robinson has also interviewed a prominent Hindu nationalist in India, namely, Tapan Ghosh, who visited the UK to speak about the threat of Islam (see Figure 9). ${ }^{5}$ A former member of the RSS and founder of Hindutva organization Hindu Samhati, Robinson describes Ghosh's organization as having the aim to "protect the Hindu community, protect their women. All the same problems we face, they face." Again, we see that "native" women-whether Hindu or white Europeans-face a common enemy from hypersexual Muslim men.

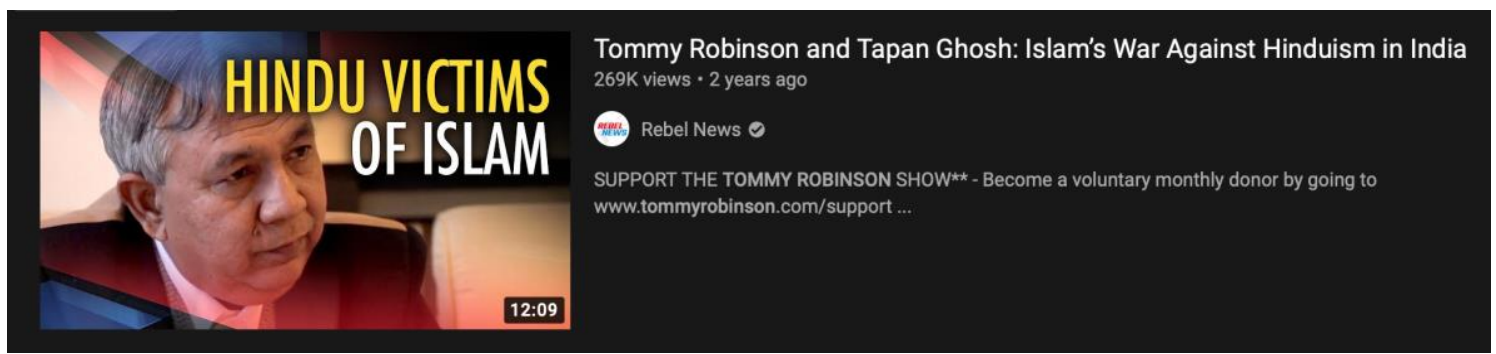

Figure 9. A screenshot of the YouTube video featuring an interview between Tapan Ghosh and Tommy Robinson.

As Robinson says to Ghosh during their interview:

I've heard of the term love jihad. It's mad cause in our country we have a mass scandal going on, which is grooming ... [Love jihad] is exactly the same as 
what's happening here. The problems in India, you're ten or fifteen years ahead of us.

Robinson continues by highlighting a solution devised by Ghosh:

You've set up an organization which has a 100,000 young Hindu men who volunteer to protect your community, to protect your daughters.

By signalling that young Hindu men must stand together to defend "their" women from threatening Muslim men, Robinson once again frames women as vulnerable "daughters" in need of protection. The female victims are portrayed as naïve, innocent, and with no agency in their decision making regarding romantic relationships. This presents an interesting contrast to the far-right female influencers above, who, despite engaging in similar victimhood narratives, do not explicitly call upon men to take action as protectors of young women. Instead, they encourage their viewers to "make noise" and raise awareness of this issue, indicating that both men and women can collectively play a role in challenging grooming activity. Robinson, on the other hand, promotes men's sense of ownership and entitlement over "our" women.

Robinson's activism in the counter-jihad milieu has likewise been noticed among Hindu nationalists in India. Later that year after interviewing Ghosh, Robinson was arrested and imprisoned for livestreaming outside the court during the trial of the Huddersfield grooming gang case after the judge had ordered reporting restrictions. Robinson was charged for contempt of court by publishing information about the case that could prejudice an ongoing trial. Robinson's imprisonment caused a backlash from far-right supporters, who campaigned using the hashtag \#FreeTommy. Rajiv Maholtra, a prominent Hindu nationalist ideologue, posted on Twitter in support of Robinson (Figure 10).

\section{Tommy Robinson jailed in UK for filming the trial of \\ Muslims accused of Love Jihad. Is this British judge \\ suppressing freedom of the press? \\ foxnews.com/world/2018/05/}

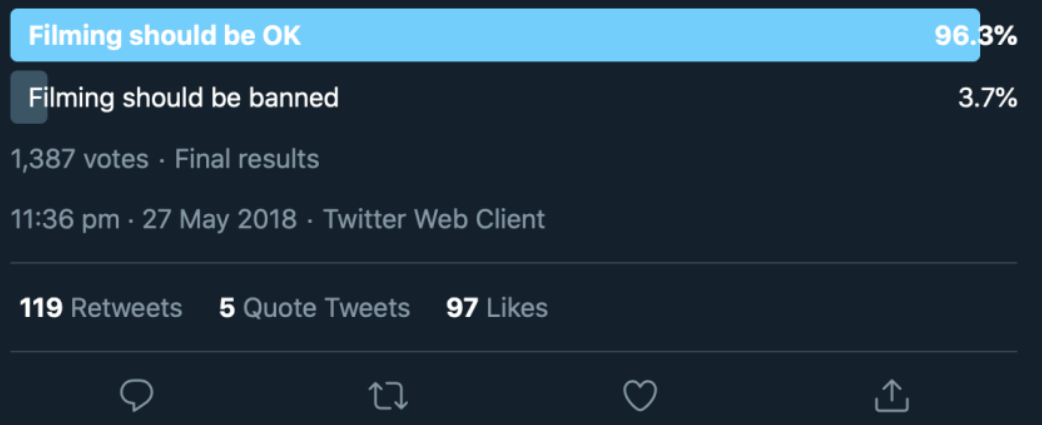

Figure 10. Tweet by Rajiv Malhotra supporting Tommy Robinson.

Maholtra's tweet reads, "Tommy Robinson jailed in UK for filming the trial of Muslims accused of Love Jihad. Is this British judge suppressing freedom of the press?" Here, Hindu nationalists are directly associating Robinson's activism exposing grooming gang activity with love jihad (despite the fact that the case has no explicit mention of love jihad). That Hindu nationalists understand grooming gangs using the vocabulary of love jihad signals the deep interconnection between Western far-right and Hindutva narratives in framing the sexuality of Muslim men; this trope operates transnationally to reproduce gendered nationalist imaginaries that are centered upon "native" women needing to be "saved" from the violent barbarism of Islam that is manifested through Muslim masculinity. 
While Robinson occupies a pivotal role in bridging love jihad and grooming gang narratives between these otherwise disaparate far-right milieus, his rhetoric also reveals a gendered disconnect between male and female far-right actors. Influencers like Sellner and Southern engage in the same fear mongering surrounding Muslim men and Islamification through sexual violence. However, they do not propose a one-sided solution that is centered upon militant masculinity in order to "protect" women; rather, women have agency to vocalize their concerns and consequent action must involve cooperation between women and men-an act of solidarity not recognized by Robinson who advocates for men's proprietary rights over "our" women.

\section{Discussion}

This article compares two case studies that involved the framing of Muslim male hypersexuality by Hindu nationalist and European/North American far-right female influencers, namely, the Nikita Tomar incident and grooming gang scandals in the UK. Despite some slight variation that can be attributed to local context, these far-right movements share similar tropes concerning the representation of Muslim men as savage and barbaric; Muslim sexuality as an instrumentalized tool of demographic warfare toward achieving the "Islamization" of India and Europe; "native" Hindu and white women (i.e., "our daughters") constantly existing in a vulnerable state and needing protection by militant Hindu and white men; an invoked sense of urgency to save Hindu and Western civilization; and complicity of the mainstream media, entertainment industry, and the political left in allowing for, and sometimes promoting, these alleged pro-Muslim and pro-Islam abusive practices. These overlapping themes centre upon shared anxieties about the politics of reproduction as linked to gendered nationalist imaginaries.

Examining the discourse and framings of these Hindu nationalist and Western far-right female influencers reveals how sexuality and gender constructions emerge as signifiers of the national collectivity. However, while these women reproduce gendered logics of femininity and masculinity, they also, in some ways, challenge our understanding of gender as it relates to far-right movements. By positioning themselves as visible de facto leaders and commentators, these far-right activists re-imagine a "feminist" politics: one that remains exclusionary yet disruptive of a male-dominated milieu, whether it be within the European/North American far-right scene, such as Sellner and Southern's differing views on female agency vis-à-vis Tommy Robinson, or Agarwal's highly public profile within conservative Indian society. By focusing on gender and sexuality through the narratives of love jihad and grooming gangs, these influencers find opportunities to be engaged in political activism, perhaps in ways otherwise unafforded to them.

What marks these far-right women as distinct from their predecessors is how they deliver the message: as influencers they cultivate an audience through a social media performance. These Hindu nationalist and Western far-right female influencers rely upon a network that is attuned to their sensationalist and reactionary rhetoric, which is bolstered by platform affordances, such as algorithm recommendations, likes, comments, and shares. Fundamentally, they exploit dynamics of the online attention economy to promote an exclusionary political ideology that is in line with a personal brand. Whether streaming a YouTube video via webcam in order to "reveal" the truth about ongoing Hindu genocide, or a government cover up of mass organized sexual exploitation, these far-right female influencers tap into their viewers' fears of orchestrated sexual violence through intimacy techniques. The transnationalization of Muslim male hypersexuality is not only ideologically driven, it is also technologically enabled. Islamophobic narratives circulate in a global digital ecosystem that permeates across national borders.

As Thobani (2019) observes in the convergence between Hindu nationalist and Western far-right movements, what transpires is a "productive synergy that exists between distinct nationalist projects in the transnational present. This synergy results from, but is ultimately greater than, the common ground the two ideologies share in delineating their individual nationalist visions against the same 'significant Other' — namely the figure of the Muslim" 
(p. 747). Thus, Islamophobic tropes are foundational toward situating a shared connection between these otherwise disparate exclusionary nationalist movements. However, more integral is positioning how Islamophobia is invoked, mobilized, and operationalized within the nationalist myth-making process.

Funding: This research was funded by the Research Council of Norway grant number 287230.

Institutional Review Board Statement: The study was conducted according to the guidelines of the Declaration of Helsinki, and approved by the Ethics Committee of the Norwegian Center for Research Data (NSD) (project code: 594174, date of approval: 18 June 2020).

Informed Consent Statement: Informed consent was waived upon approval from the Norwegian Center for Research Data (NSD) due to risk concerns.

Data Availability Statement: The data presented in this study are available in the article.

Conflicts of Interest: The author declares no conflict of interest.

\section{Notes}

1 https:/ / ishittva.org (accessed on 28 October 2021).

2 On the other hand, Agarwal does employ more traditional practices of microcelebrity on her Instagram page, posting photos of homecooked Ayurvedic foods, spiritual books she is reading, and practicing meditation.

3 Video has been taken down from YouTube but is accessible on Brittany's BitChute channel as "Fighting Islamization with Tommy Robinson", uploaded 27 October 2017, https: / / www.bitchute.com/video/6GAi4jiZQB4/ (accessed on 28 October 2021).

4 See for example, “The Tommy Robinson Interview That Got Me Banned From The U.K.," 14 March 2018, https:/ / www.youtube. $\mathrm{com} /$ watch? $\mathrm{v}=\mathrm{WnQ} 3 p m D j f k c \& \mathrm{t}=1 \mathrm{~s}$ (accessed on 28 October 2021).

5 “Tommy Robinson and Tapan Ghosh: Islam's War Against Hinduism in India”, 23 January 2018, https: / /www.youtube.com/ watch?v=MMZjUiJSsQY (accessed on 28 October 2021).

\section{References}

Abidin, Crystal. 2015. Communicative Intimacies: Influencers and Percieved Interconnectedness. Ada: A Journal of Gender, New Media, and Technology 8: 1-16.

Ahmed, Saifuddin, Jaidka Kokil, and Jaeho Cho. 2016. The 2014 Indian elections on Twitter: A Comparison of Campaign Strategies of Political Parties. Telematics and Informatics 33: 1071-87. [CrossRef]

Bacchetta, Paola. 1993. All Our Goddesses are Armed: Religion, Resistance, and Revenge in the Life of a Militant Hindu Nationalist Woman. Bulletin of Concerned Asian Scholars 25: 38-52. [CrossRef]

Bangstad, Sindre. 2013. Eurabia Comes to Norway. Islam and Christian-Muslim Relations 24: 369-91. [CrossRef]

Bangstad, Sindre. 2019. Bat Ye'or and Eurabia. In Key Thinkers of the Radical Right. Edited by Mark Sedgwick. Oxford: Oxford University Press, pp. 170-84. [CrossRef]

Bar-On, Tamir. 2007. Where Have All the Fascists Gone? London: Routledge. [CrossRef]

Bhatt, Chethan. 2004. Democracy and Hindu Nationalism. Democratization 11: 133-54. [CrossRef]

Blee, Katheleen M. 2002. Inside Organized Racism: Women in the Hate Movement. Berkeley: University of California Press.

Brubaker, Rogers. 2017. Between Nationalism and Civilizationism: The European Populist Moment in Comparative Perspective. Ethnic and Racial Studies 40: 1191-226. [CrossRef]

Chadha, Kalyani, and Pallavi Guha. 2016. The Bharatiya Janata Party's Online Campaign and Citizen Involvement in India's 2014 Election. International Journal of Communication 10: 4389-406.

Chakravartty, Paula, and Srirupa Roy. 2015. Mr. Modi Goes to Delhi: Mediated Populism and the 2014 Indian Elections. Television and New Media 16: 311-22. [CrossRef]

Cockbain, Ella, and Waqas Tufail. 2020. Failing Victims, Fuelling Hate: Challenging the Harms of the 'Muslim Grooming Gangs' Narrative. Race E Class 61: 3-32. [CrossRef]

Darby, Sayward. 2020. Sisters in Hate: American Women on the Front Lines of White Nationalism. New York: Little, Brown and Company.

Davey, Jacob, and Julia Ebner. 2019. 'The Great Replacement': The Violent Consequences of Mainstreamed Extremism. London: Institute for Strategic Dialogue. Available online: https://www.isdglobal.org/wp-content/uploads/2019/07/The-Great-Replacement-TheViolent-Consequences-of-Mainstreamed-Extremism-by-ISD.pdf (accessed on 28 October 2021).

Dietze, Gabriele, and Julia Roth. 2020. Right-Wing Populism and Gender: European Perspectives and Beyond. Bielefeld: transcript Verlag. [CrossRef]

Farris, Sara R. 2017. In the Name of Women's Rights: The Rise of Femonationalism. Durham: Duke University Press.

Ganesh, Bharath. 2020. Weaponizing white thymos: Flows of rage in the online audiences of the alt-right. Cultural Studies 34: 892-924. [CrossRef] 
Govil, Nitin, and Anirban Kapil Baishya. 2018. The Bully in the Pulpit: Autocracy, Digital Social Media, and Right-wing Populist Technoculture. Communication Culture and Critique 11: 67-84. [CrossRef]

Huntington, Samuel. 1993. The Clash of Civilizations? Foreign Affairs 72: 22-49. [CrossRef]

Köttig, Michaela, Renate Bitzan, and Andrea Petö, eds. 2017. Gender and Far Right Politics in Europe. London: Palgrave Macmillan.

Leidig, Eviane. 2020a. Hindutva as a variant of right-wing extremism. Patterns of Prejudice 54: 215-37. [CrossRef]

Leidig, Eviane. 2020b. From cyber-Hindutva to Ab Ki Baar Trump Sarkar: (Trans)national entanglements of Hindu diaspora political integration. In Political Integration in Indian Diaspora Societies. Edited by Ruben Gowricharn. London: Routledge, pp. 127-52.

Lewis, Rebecca. 2018. Alternative Influence: Broadcasting the Reactionary Right on YouTube. New York: Data \& Society Research Institute.

Lewis, Rebecca. 2020. “This is what the news won't show you": YouTube Creators and the Reactionary Politics of Micro-Celebrity. Television E New Media 21: 201-17. [CrossRef]

Maly, Ico. 2020. Metapolitical New Right Influencers: The Case of Brittany Pettibone. Social Sciences 9: 113. [CrossRef]

Marwick, Alice E. 2015. Instafame: Luxury Selfies in the Attention Economy. Public Culture 27: 137-60. [CrossRef]

Mattheis, Ashley. 2018. Shieldmaidens of Whiteness: (Alt) maternalism and Women Recruiting for the Far/Alt-Right. Journal for Deradicalization 17: 128-62.

Menon, Kalyani Devaki. 2010. Everyday Nationalism. Philadelphia: University of Pennsylvania Press.

Mohan, Sriram. 2015. Locating the "Internet Hindu": Political Speech and Performance in Indian Cyberspace. Television and New Media 16: 339-45. [CrossRef]

Mondon, Aurelien, and Aaron Winter. 2017. Articulations of Islamophobia: From the extreme to the mainstream? Ethnic and Racial Studies 40: 2151-79. [CrossRef]

Pal, Joy. 2015. Banalities Turned Viral: Narendra Modi and the Political Tweet. Television and New Media 16: 378-87. [CrossRef]

Pertwee, Ed. 2020. Donald Trump, the Anti-Muslim Far Right and the New Conservative Revolution. Ethnic and Racial Studies 43: 211-30. [CrossRef]

Pilkington, Hilary. 2017. 'EDL angels stand beside their men ... not behind them': The Politics of Gender and Sexuality in an anti-Islam (ist) Movement. Gender and Education 29: 238-57. [CrossRef]

Sarkar, Tanika. 1993. The Women of the Hindutva Brigade. Bulletin of Concerned Asian Scholars 25: 16-24. [CrossRef]

Saxena, Saumya. 2018. “Court"ing Hindu Nationalism: Law and the Rise of Modern Hindutva. Contemporary South Asia 26: 378-99. [CrossRef]

Sethi, Manisha. 2002. Avenging Angels and Nurturing Mothers: Women in Hindu Nationalism. Economic and Political Weekly 37: 1545-52.

Šima, Karel. 2021. From Identity Politics to the Identitarian Movement. In National Stereotyping, Identity Politics, European Crises. Edited by Jürgen Barkhoff and Joep Leerssen. Leiden: Brill. [CrossRef]

Spierings, Niels, Andrej Zaslove, Liza M. Mügge, and Sarah L. de Lange. 2015. Gender and Populist Radical-Right Politics: An Introduction. Patterns of Prejudice 49: 3-15. [CrossRef]

Thobani, Sitara. 2019. Alt-Right with the Hindu-Right: Long-distance Nationalism and the Perfection of Hindutva. Ethnic and Racial Studies 42: 745-62. [CrossRef]

Thorleifsson, Cathrine. 2019. The Swedish Dystopia: Violent Imaginaries of the Radical Right. Patterns of Prejudice 53: 515-33. [CrossRef]

Udupa, Sahana. 2018. Enterprise Hindutva and Social Media in Urban India. Contemporary South Asia 26: 453-67. [CrossRef]

Youmans, William Lafi, and Jillian C. York. 2012. Social Media and the Activist Toolkit: User Agreements, Corporate Interests, and the Information Infrastructure of Modern Social Movements. Journal of Communication 62: 315-29. [CrossRef]

Zúquete, José Pedro. 2018. The Identitarians: The Movement against Globalism and Islam in Europe. Notre Dame: University of Notre Dame Press. [CrossRef] 